\title{
実用 講座
}

\section{自動溶接のポイント (2) アーク溶接ロボットのティーチング操作の要点*}

\section{Esence of Automatic/Semi-Automatic Arc Welding (2) \\ The Point of a Teaching Operation in Arc Welding Robot*}

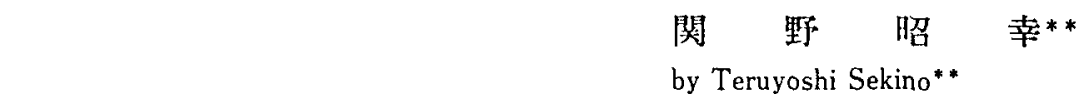

キーワード：溶接ロボット，ティーチング、ロホホット操作，フレイバック， 作筆方法, ロポット溶接

\section{1.はじめに}

最近のアーク溶接用ロボットの普及は目覚しく， 溶接自動化のツールとして重要な位置を占めている が,現在使われているロボットの大半は「プレイバッ ク型」と呼ばれるものて、、ボットを使って溶接を 行わせるには，動作する位置や速度，あるいは溶接 条件などをティーチング (教示) してやらなくては ならない。言わばロボットは，人間に教えられた通 りに動作して溶接をプレイバック（実行）するわけ で，ロボットアーク溶接オペレータにとって，この ティーチング・プレイバックに関する知識と技量の 修得は，たいへん重要なことであり確実にマスタし ておかなくてはならない。

ロボットの具体的な操作方法や用語は, 各メ一力 のロボットによって違っており，またさまざまな機 能がつけられているロボットもあって，統一して説 明することは困難であるため，ここではアーク溶接 用口ボットを操作する上て，基本となる事柄につい て述べる.

\section{2. 安全確保と作業準備}

ティーチング作業は，ロボットの可動範囲内にお

*原稿受付 平成 4 年 3 月 10 日

**正員 神戸製鋼所, Member, Kobe Steel, Ltd.
いて実施する作業であるため，まず安全の確保を図 らなくてはならない。そのための基本的な事項とし ては,

・「作業表示札」の設置

・「作業監視者」の配置

・「合図（あいず）の方法」の確認

・「異常時における措置」の確認 などが挙げられる。

「作業表示札」は，一目で現在の作業状態が分か るようにするためのもので，起動スイッチや安全栅 の入口，あるいは所内規則で定めた所などに,「教示 作業中」の表示札をつけておかなくてはならない。

またティーチング作業を行う場合には，作業を監 視する人を配置することが望ましい，これは，異常 時の措置（例えば，非常停止ボタンを押すなどの措 監）がただちに実行できるようにしておく目的のほ かに, 関係者以外の人の立入りや起動ボタンの不用 意操作を末然に防止したり，ティーチング作業を 行っている人が危険状態（例えば，万一の場合に逃 場がない所にいるなど）にならぬよう監視するなど の目的である。

ティーチング作業を実際に行うには，それに先 立って以下のことを確認あるいは実施しておく必要 がある。

・「溶接トーチの芯合わせ」の確認

・「溶接ワイヤの笑出し長さ」の確認 
・「非常停止機能」などの点検

・「原点復瓻動作」の実行

・「位置確誌用プログラム」の実行

・「リモート操作速度」の設定あるいは確認

「溶接トーチの芯合わせ」はロボットの作業基準 点と溶接中のアーク発生点とが一致するように, 溶 接トーチをロボットの手首先端に取付けることで， その際「溶接ワイヤの突出し長さ」も所定量になる よう調整しておく必要がある。

「非常停止機能」の点検では, 制御盤面や教示用 ペンダントの非常停止ボタンについて確認するほ か, ロボット作動の異常の有無, 周辺装置や治具な どとの各種インターロック機能についても点検して おくことが望ましい。

また「原点復州動作」の実行で，その正常終了 とともに，プレイバック位置精度の確認を行うため 「位置確認用プログラム」を実際にプレイバックし て，プレイバック等の位置ずれがないことを確認し ておくとよい。

位置確認用プログラムというのは，架台や治具な どに固定点を設けてその点をティーチングしたもの で，さまざまな手首姿勢をとらせたり固定点を何点 か設けて，万一ずれが発見された時にどの軸のずれ であるかが推定できるようにしておくなどの工夫が あるとさらによい，またこの方法は，位置ずれの原 因がワーク側にあるのかロボット側にあるのかを見 分けたり，溶接卜ーチ交換時の取付け姿勢や位置の 目安にしたり，あるいはチップの摩耗や溶接ワイヤ の曲がりぐせ矯正不良の発見にも役立つため，たい へん便利である。

「リモート操作速度」は，ティーチングのモード が設定されたり，安全栅入口屝が開放されたりする と，自動的に安全な速度に隇速されるようになって いるが，口ボットによっては，熟練度や作業状況に 応じて速度の選択ができるようになっているものも あるので, 操作キーと動作方向の確認も兼ねて, チェックしておくといよい.

\section{3. ティーチング作業の実際}

アーク溶接用ロボットでは, 基本的には

・ティーチング

・ティーチングチェック

・プレイバック

という3つの操作を行わなくてはならない. また必 要に応して、ティーチングデータの編集を行う.

\section{1 ティーチング}

（1）モードの設定と起動

前項に挙げた操作は，まずどの操作を行うのかと いう「操作モードの設定」ということから始める. ロボットによっては「ティーチング」と「ティーチ ングチェック」は, 同じモードで行うもの，また別々 のモードで行うものもある。

各モードの設定方法は，各メーカのロボットに よって異なるが, セレタスイッチあるいは何らかの 方法で「ティーチング」を選択し，モードを設定す るスイッチをオンにするか，あるいは「ティーチン グ」という押しボタンスイッチをオンにすることで 「ティーチングモード」が設定されるというのが, よく行われている方法である，そしで後述する ティーチングテータの番号を設定してから, 起動ボ タンを押してティーチングモードに入るようになっ ている.

またこの「モードの起動スイッチ」は, ロボット 動作筙囲外に固定された制御盤に設けられており, 不用意操作を避けるため，ガードやふたなどがつけ られていて, 安全の確保が図られるようになってい る.

（2）ティーチングの作業手順

ティーチング作業では,

・「ティーチングモード」の選択

・「ティーチングデータの番号」の設定と， 「ティーチングモード」の起動

・「動作すべき位固（教示点)」と，

「溶接トーチ姿勢」の教示

・各教示点ての「命令データ」の設定 を行うことが基本的な操作である。

図 1 はティーチング作業の手順例を示したものて ある。

まず, ティーチングデータ(プログラム, ジョブ, ブロックなどとも呼ばれる) の番号を設定し, 起動

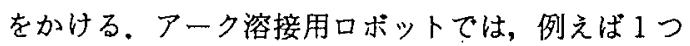
の溶接線をティーチングするには特別な場合を除け ば最低 4 つの教示点が必要で,これら一つづきの教 示点の集まりに対して，番号を設定して区分けする ようになっている*.

\footnotetext{
*ティーチングデータに名称をつけられるロボットもあ るが、ティーチングデータは番号で管理されるように なっているのが一般的なので,どのワークがあるいは どの溶接線が何の番号てティーチングされているかと いう一覧表をつくって管理する必要がある。
} 


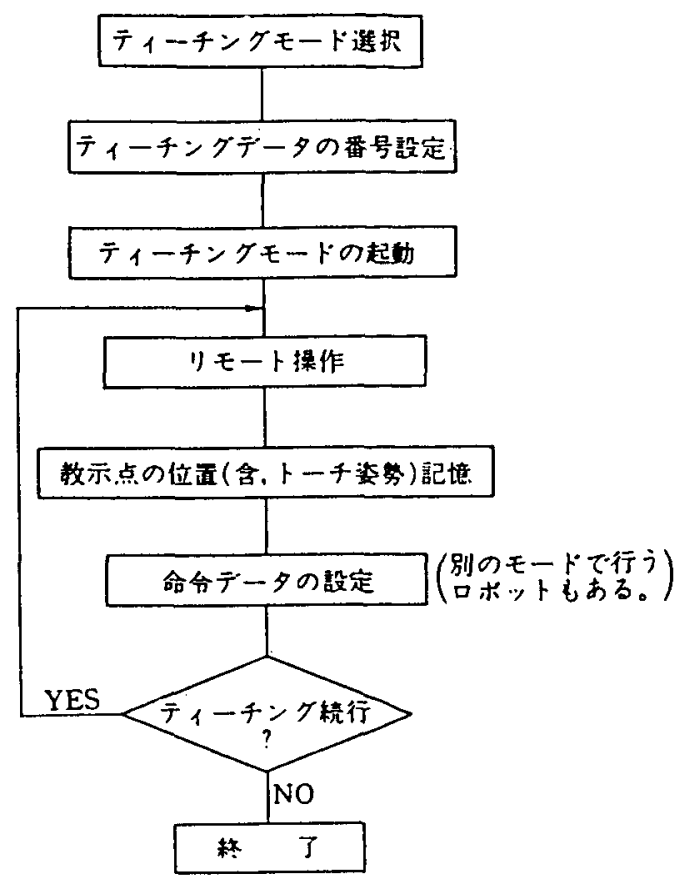

图 1 ティーチング作業の手順例

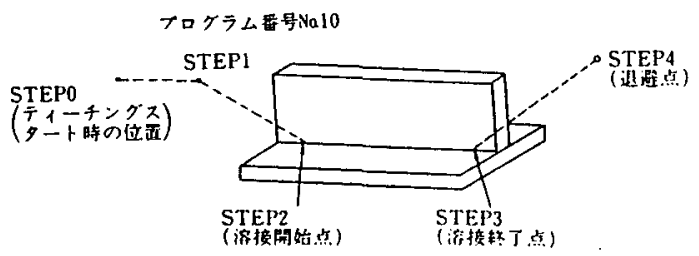

图 21 ○の溶接線のティーキング例

「教示点」は，ポイントあるいはステップなどと も呼ばれ，リモート操作でロボットをその動作すべ き位置まで夷際にもっていって, 位置記憶（教示, あるいはインプット)ボタンを押すことで，その「動 作点の位置」が教示され, ロボットの内部メモり (RAM) の中にその位膡データが記境される。

この教示点が, 溶接線の開始点, 途中点, 終了点 である場合には，位置の教示とともに「溶接トーチ の姿勢」も教示しなくてはならない.これは，溶接 トーチをその溶接線に合った角度姿勢に実際に整え て，位置教示することで行われる。

図 2 に, 1 つの溶接線のティーチング例を示す. この時のリモート操作は

・各軸ごとに動かす操作

・ロボットの座標軸に治う操作 などがあり，ロボットによって，そのどちらかで動 かすもの，あるいはどちらかを選択できるものなど
がある.この操作は，ティーチングボックあるいは ペンダントと呼ばれるリモート操作盤のキーを操作 して行う。

また，リモート操作の速度は「低速」「高速」など を選択できるようになっているのて，ワークゃクラ ンプ治具に近い所では「低速」に，またそれらから 遠い所では「高速」にするなどこまめな切換えが必 要である。この時の速度は, プレイバック時，すな わち実際稼働時のロボットの動作速度とは関係ない のて，技量に応じた速度を選択するとよい。このリ モート操作は，常日頃から練習を重ね十分熟練して おく必要がある。

「命令データ」というのは, パラメータ, 命令コー ドなどとも呼ばれ，各教示点での制御条件，すなわ ちエアカット速度, 溶接条件, センシングコード, 外部機器への指令出力, 外部機器の状態確認などを 行うための信号である。これらの具体的設定方法は 各メーカのロボットにより違っており，例えば溶接 条件では，実速度，実電流で入力すものや，それ らをコードて入力するもの，あるいは開先の種類と 脚脣を指定するだけで，所要パス数と各パスのシフ 卜位置枋よび溶接条件が自動的に設定されるものな ぞ,さまざまである。

以上はアーク溶接用ロボットのティーチング操作 における基本的なことであるが，よりよいロボット 溶接結果を得るためには，さらに以下のことにも注 意を払わなくてはならない。

・各溶接線に合った溶接姿勢と溶接条件の設定

・センシング機能の有効利用

・エアカット動作における無䭾な動きの排除

このうちセンシング機能については, 文献 1)に詳 述されているのて，ぜU参考とされるよう招すすめ したい.

（3）直線補間と円弧補間

アーク溶接用ロボットは，基本的にはティーチン グされた教示点間の軌跡を演算してプレイバックす るようになっている。すなわちティーチングされた 2 点間づつを直線，あるいはどれかの軸で結ぶ補間 演算を行い，それを細かな制御周期ごとの位置デー タに割出して制御しているのであるが、溶接線は直 線とは限られておらず，円や円弧あるいはくら形な どがあるため、アーク溶接用ロボットでは, 直線補 間と円弧補間を組合わせてティーチング・プレイ バックできるようになっている。

直線は 2 点, 円弧は 3 点のティーチングを行うよ 


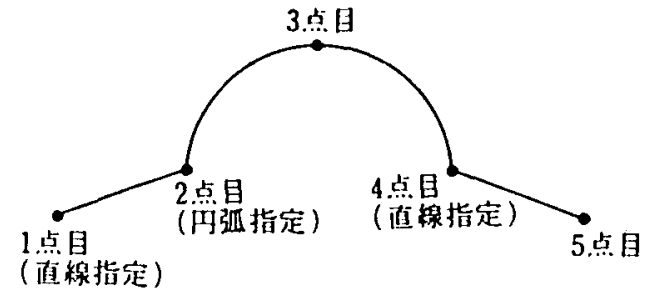

图 3 直線と円弧のティーチング例

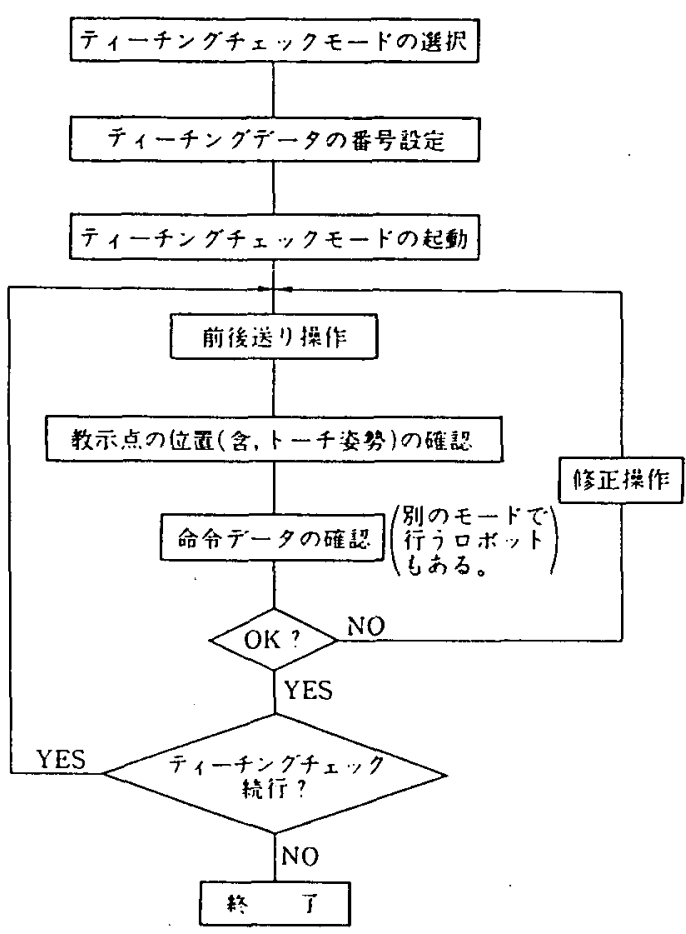

园 4 ティーチングチェックの手順例

うになっており，また 3 点以上の点を結んで自由曲 線としてティーチングできるようになっているロ ボットもある。

図 3 に直線と円弧のティーチング例を示す.

\section{2 ティーチングチェック}

(1) ティーチングチェックの目的

ティーチングチェックは,

・各教示点位置やそれを結ぶ軌跡,

及び溶接トーチの姿势が正しいか

・各教示点での命令データに間違いがないか

・周辺装置の治具の動きは正しいか

を確諗する目的で行うもので，プレバックを行う 前に必ず一度は実施しておかなくてはならない。し たがってこの作業は，ティーチング作業の仕上げと 考えてよい。
（2）ティーチングチェックの作業手順

ティーチングチェック作業では，モードを起動し た後,

・「教示点間の前後送り操作」による

軌跡及び溶接姿勢の確認と修正

・各教示点における「命令データ」の確認と修正 を行うことが基本的な操作となる.

ティーチングチェックモードは，テストプレイ バック，テスト運転などとも呼ばれ，前述のように ティーチングモードと一緒になっているものや別々 になっているものもある．また，ロボットの動きを 止めておいて周辺装置や治具類だけ動きをチェッ クする機能，あるいは命令データだけのチェックを する機能などがついているロボットもある。

以下図 4 に示すように，ごく一般的に行われてい る手順について述べる。

まず「ティーチングチェック」のモードを選択し, これから確認しようとする「ティーチングデータの 番号」を設定してから起動ボタンにより，モードを 起動する。この時, この番号とワークとに間違いが ないよう十分に注意しなくてはならない.

つぎに「教示点間の前後送り操作」を行いながら， チェック作業に入る。ここでのポイントは, 思い通 りのティーチングができているのかということにな るが, 軌跡や姿勢については, 特に以下の点に注意 を払う。

・溶接の順序, ロボットの移動のさせ方は正しい か.

・ティーチング時に思い違いをしていないか

(抜けやダブリのチェック).

・各溶接線に対する溶接トーチの姿攀, ねらい位 置は正しいか.

（溶接線全線に対してロボットを動かして確認す

もちろんワークや治具との干涉があってはならな いし，不具合があれば修正しなければならない，修 正には「変更」「追加（挿入）「消去」があるが,一 般的には修正をしたい教示点まで前後送りあるいは リモート操作でロボットを移動させ，そこで修正操 作を行うという手順で行われる，また，表示機能の ついているロボットでは, 各教示点の座標值や口 ボット手首の角度データを呼び出し, 修正データを 数值でインプットして修正する機能をもつロボット もある。

命令データの確認では，以下の点に注意を払う。 
・エアカット速度

・溶接条件（電流・電圧・速度・クレータ条件な ど)

・アークのオン・オフ

・外部機器（クランプ治具など）への出カオン・ オフ

・外部機器（リミットスイッチなど）功らの状態 入力

・センシングコードの使い方

これらの修正の操作方法は，ロボットによりさま ざまであるが，ロボットをその教示点まで実際に移 動させた上で命令コードを表示させて修正を加える 方法と、ロボットを動かさずに所望教示点の命令 データを呼び出し表示させて修正を加える方法があ る.

以上のようにしてティーチングデータのチェック が終わると，いよいよ「プレイバック」をさせて確 認することになる。

\section{3 プレイパック}

（1）作業準備

プレイバックを行う場合は，ロボットの稼働筙因 内あるいは安全妌内に人が立ち入ってはならない し，安全棚入口韮も閒めた状態とし，さらに「作業 表示札」の設置などの安全確保を図らねばならない.

また 2 項に述べた作業準備のほか，溶接ワイヤの 残量やシールドガス流量の点検も行われていなくて はならない。これらは，ロボットアーク溶接を行う 際の作業準備として基本的なことである。

(2) プレイバック時の注意点

ロボットの操作としては,「プレイバックモード」 の選択,「データ番号」の設定と「モード」の起動と いう手順になるが、「プレイバックの起動」は前項ま での場合と違い, ロボットはすぐに動作を始めるこ とになるので，今一度の状況確認が必要とである。 特に周辺装置やクランプ治具と組合わせているシス テムでは，それらのチェックも必要である。

ティーチングしてはじめてのプレイバックでは, 正常終了するまで, 状況を監視する必要がある。こ の時には，溶接の状況，口ボットの動きなどをよく 観察し，不具合や気づく所があ九ば修正を加兄てお
かねばならない.プレイバック途中での修正は，各 ロボットの操作説明畫に従い, 慎重に行う必要があ 3.

またてでき上った製品の状態も入念にチェックし， 必要があれば検査工程にまわすなどの措置をとる。 その他，常々運転しているプログラムであっても， 不具合があれば原因を確かめて修正を加えるなど， 日常のこまめな努力も必要である。

\section{4 ティーチングデータの保存}

ティーチングデータは制御装置の RAM(ラム)と 呼ばれる内部メモりに記境されており，プレイバッ クする時には必要なデータを読み出してロボットを 運転している。この内部メモリの容量には限りがあ りここれを超えてはデータを記境することはできな いため, 記憶容量が限度近くになった時には，その データを外部のメモりに移し保存して扔かなくては ならない。

また, RAM に記憶されているデータは, 停電時に も保持できるようバッテリでバックアップされてい る。しかしバッテりには容量的な限界や寿命もある ため，万一の場合にもデー夕を消失してしまうよう

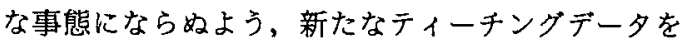
つくった時やティーチングデータに修正を加えた時 には，必ずそのデータを外部メモりにセーブ(格納) しておくことが大切である。

\section{4.おわりに}

以上アーク溶接用ロボットを蝶作する上で，基本 となる事柄について，特にティーチング操作を中心 に述へた。

ロボットアーク溶接オペレータにとって，ロボッ 卜操作に関する知識と技量の修得はたいへん重要な ことであり，常日頃から実地での訓練に励み，その 向上に努めることか大切であるが，そのために少し でも参考になれば，幸いである。

\section{参 考 文 献}

1）溶接学会溶接法研究委具会編：アーク溶接に扔け るセンシングと制御（1990 年 5 月） 